\title{
The enigma of in vivo oxidative stress assessment: isoprostanes as an emerging target
}

\author{
Samar Basu
}

Clinical Nutrition and Metabolism, Department of Public Health and Caring Sciences, Faculty of Medicine, Uppsala University, Uppsala, Sweden

Abstract

Oxidative stress is believed to be one of the major factors behind several acute and chronic diseases, and may also be associated with ageing. Excess formation of free radicals in miscellaneous body environment may originate from endogenous response to cell injury, but also from exposure to a number of exogenous toxins. When the antioxidant defence system is overwhelmed, this leads to cell damage. However, the measurement of free radicals or their endproducts is tricky, since these compounds are reactive and short lived, and have diverse characteristics. Specific evidence for the involvement of free radicals in pathological situations has been difficult to obtain, partly owing to shortcomings in earlier described methods for the measurement of oxidative stress. Isoprostanes, which are prostaglandin-like bioactive compounds synthesized in vivo from oxidation of arachidonic acid, independently of cyclooxygenases, are involved in many human diseases, and their measurement therefore offers a way to assess oxidative stress. Elevated levels of $\mathrm{F}_{2}$-isoprostanes have also been seen in the normal human pregnancy, but their physiological role has not yet been defined. Large amounts of bioactive $\mathrm{F}_{2}$-isoprostanes are excreted in the urine in normal basal situations, with a wide interindividual variation. Their exact role in the regulation of normal physiological functions, however, needs to be explored further. Current understanding suggests that measurement of $F_{2}$-isoprostanes in body fluids provides a reliable analytical tool to study oxidative stress-related diseases and experimental inflammatory conditions, and also in the evaluation of various dietary antioxidants, as well as drugs with radical-scavenging properties. However, assessment of isoprostanes in plasma or urine does not necessarily reflect any specific tissue damage, nor does it provide information on the oxidation of lipids other than arachidonic acid.

Keywords: antioxidants; free radicals; human; inflammation; isoprostanes; oxidative strain; oxidative stress

\section{Introduction}

$\mathrm{O}$ ne of the major common features of acute and chronic diseases, which cause high morbidity and mortality globally, is the surplus formation of various free radicals (reactive oxygen or nitrogen species). These can originate from reactions to cell injury in general, incorrect activation of phagocytic cells in chronic inflammatory situations, diminished levels of antioxidants, etc. Free radicals are formed endogenously within the cell during diverse metabolic processes in vivo, and can also be formed endogenously upon exposure of the body to a number of toxins, pesticides, pharmaceutical agents, environment pollutants, radiation injury, etc. However, the formation of free radicals is also an indispensable part of normal cell metabolism. Once biosynthesized, these molecules may serve as bioregulators of several functions of the body through signal transduction, thus involving diverse biochemical processes. This leads to further exclusive formation of new biomolecules that are necessary to maintain normal homoeostasis, signal transduction and protein function, and to ensure cell survival.

However, the measurement of free radicals or their endproducts is difficult, particularly since the free radicals are very reactive and spontaneously short lived. Therefore, scientists have primarily focused on the detection of endproducts or their by-products, which have quite diverse characteristics. In 1989, William A. Pryor, Co-Editor-in Chief of Free Radical Biology and Medicine, cited: "One of the greatest needs in this field now is the availability of non-invasive tests to probe oxidative stress status in humans". The lack of such tests has been a major obstacle not only in exploring the 
pathogenesis of various oxidative stress-related diseases, but also in evaluating the epidemiological findings regarding vitamins and diseases and in designing a rationale for therapeutic targets against the free radical-mediated diseases. Such data are needed to resolve the constant debate on the role of antioxidants in various diseases.

Isoprostanes are a newly discovered group of prostaglandin-like compounds, which are biosynthesized from esterified arachidonic acid through a non-enzymic free radical-catalysed mechanism and have very short half-lives (16 $\mathrm{min}$ in humans and about $4 \mathrm{~min}$ in rabbits) (1-3). Several of these compounds retain biological activities, as confirmed mainly by pulmonary and vasoconstrictive, and even inflammatory activities $(2,3)$. Both human and experimental studies reveal that isoprostanes are augmented in both acute and severe chronic inflammation, ischaemia-reperfusion, diabetes, atherosclerosis, obesity, lung and liver diseases, etc (see Table 1). Furthermore, existing evidences advocate that isoprostanes are authentic indicators of free radical-mediated lipid peroxidation and oxidative stress $(2,4)$. Having potent biological activities and also involvement in both normal physiology and pathophysiology, the measurement of these compounds has attracted huge attention, evident from an exponential increase in the number of publications in the field since mid1990s. However, it is to be remembered that assessment of isoprostanes in plasma or urine does not necessarily provide information on any specific tissue damage unless it is performed in certain tissue or fluids collected from the tissue in question, and it does not reflect oxidation of lipids other than arachidonic acid.

\section{Lipid peroxidation in relation to oxidative stress}

In a wider designation, lipid peroxidation in the organic systems involves all oxidation of fatty acids that occurs in vivo. Lipid peroxidation can occur rapidly in the body through both enzymic and nonenzymic reactions, the latter being primarily focused in most studies. The enzymic pathway is well documented in the oxidation of arachidonic acid through cyclooxygenases and lipoxygenases with the formation of bioactive prostaglandins, leukotrienes or lipoxins, respectively (5-7). This review will primarily cover free radicals mediated by nonenzymic lipid oxidation products. One important reason for the key roles of these free radicals is the fact that free radical-catalysed oxidized lipids can instantly modify the cell membrane fluidity, which in turn can interact with the different membraneadhering enzymes and membrane-bound receptors. In addition, many of these oxidized lipids may possess bioactivity as vasodilators or vasoconstrictors/bronchoconstrictors, or induce inflammation in neighbouring cells (see below).

It is well acknowledged that polyunsaturated fatty acids (PUFAs) with two or more double bonds are more prone to oxidation than the saturated and monounsaturated fatty acids (8). This is largely due to the instability (weak energy of attachment) of the hydrogen atom adjoining the double bond. This means that the hydrogen atom can be abstracted easily through a reactive radical attack (Fig. 1). Lipid peroxidation in vivo requires a PUFA and an oxidant inducer, which form a free radical intermediate. The free radical intermediate reacts with oxygen to form a peroxyl radical (LOO.). The unpaired electrons of the peroxyl radicals further abstract a hydrogen atom from another PUFA to form a lipid hydroperoxide, which may decay to form alkoxyl or peroxyl radicals. These radicals may also attract adjoining diverse membrane proteins. The reaction of the peroxyl radical with other fatty acids generates a carbon-centred radical which, in turn, will be able to react with oxygen to form another peroxyl radical. This radical continues its reaction to the PUFAs, and a propagation reaction initiates a chain reaction that is maintained until a termination

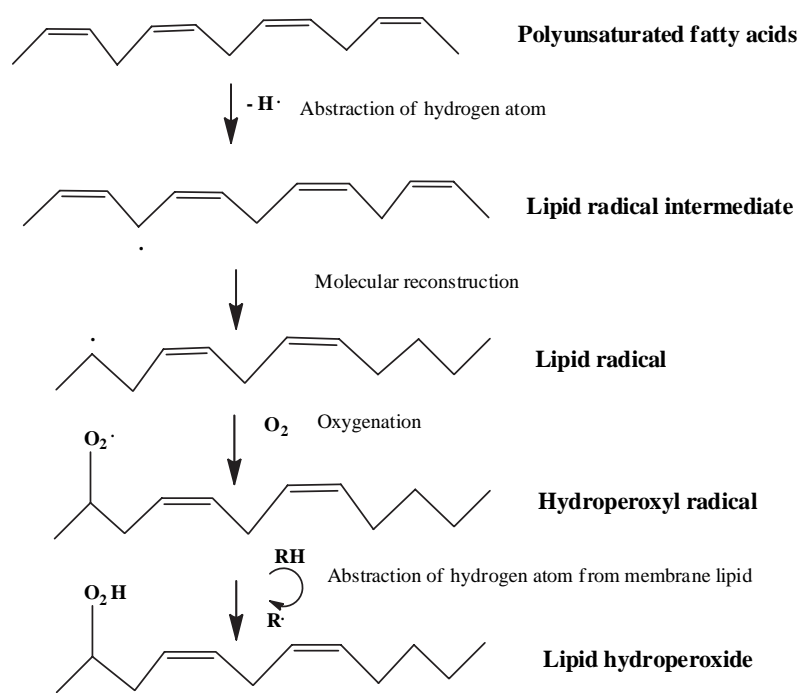

Fig. 1. Basic principle of non-enzymic lipid peroxidation involving polyunsaturated fatty acids. 
reaction starts by one or several endogenous chainbreaking antioxidants or by exogenously applied antioxidants, dietary radical scavengers or drugs (9). However, excess endogenous formation or exogenous administration of these biocombating factors may also lead to pro-oxidative effects in certain conditions which, so far, have been less studied.

The oxidative reaction processes are often perceived as being merely destructive in nature. However, they are also crucial elements of normal human body functions, as essential actors in biochemical reactions involved in the control of physiological functions such as cell signalling, vascular tone, cell generation and degeneration, and defence against microorganisms (10-14). The physiologically essential reactive species seem to be necessary to maintain the normal basal oxidant-antioxidant balance and host defences in the mammalian system. However, when a surplus formation of these bioactive oxidation products exceeds the capacity of endogenous cellular antioxidant defence mechanisms, these products may intricate in various cell and organ damage by upsetting the normal physiology in such a fashion that they instigate and/or speed up the disease processes. Furthermore, overstressed or damaged cells in disease conditions will perhaps initiate the production of these active compounds in vivo and consequently inflate cellular or damage that potentiates the disease process.

\section{Isoprostanes as biomarker of in vivo lipid peroxidation}

Indications of non-enzymically auto-oxidized prostaglandin-resembling substances arising from unsaturated fatty acids were first demonstrated in vitro in late 1960s $(15,16)$, and also frequently seen in the laboratory after storage of arachidonic acid in the freezer. However, the biological significance of these prostaglandin isomers in vivo was not uncovered until 1990. The discovery of isoprostanes was the starting point of a new era in the detection and quantification of free radical-catalysed lipid peroxidation products (1). Isoprostanes are stable lipid peroxidation products after experimental oxidative injury $(4,17)$. Besides having selective bioactivity, esterified isoprostanes may also exert biological effects within the cells where they are formed through reaction with the adhering tissues (3).
The formation $\mathrm{F}_{2}$-isoprostanes primarily requires arachidonic acid, molecular oxygen and free radicals. Unlike cyclooxygenase (COX)-derived primary prostaglandins, isoprostanes are formed in situ esterified with tissue phospholipids and subsequently released in free acid form following hydrolysis, presumably by phospholipases $(18,19)$. The enzymic cleavage step is also, at least theoretically, an important rate-limiting step for the formation and release of free isoprostanes in the circulation, which can be synchronized by variety of endogenous or exogenous factors (20). A simplified scheme of the formation of $\mathrm{F}_{2}$-isoprostanes from arachidonic acid is shown in Fig. 2.

8-Iso-prostaglandin $\mathrm{F}_{2 \alpha}$ (8-iso-PGF $2 \alpha$; Fig. 2), a major $\mathrm{F}_{2}$-isoprostane, and its related isomers are augmented significantly in a number of syndromes that are thought to be associated with oxidant injury, and the measurement of $\mathrm{F}_{2}$-isoprostanes in a range of tissues and body fluids is generally regarded as a trustworthy biomarker for in vivo determination of lipid peroxidation by free radical pathways $(1,4,9,17,20)$. 8-Iso-PGF $2 \alpha$ has about 10 times higher basal levels than enzymically produced $\mathrm{PGF}_{2 \alpha}$ and the free form of this compound is easily detectable in numerous body fluids by sensitive and specific analytical approaches. Measurement of the esterified and free isoprostanes is suitable in the tissues, and thus could be used as an approach to oxidative stress measurement for target tissue injury of interest $(21,22)$. Specific antibodies to the isoprostanes can also be applied
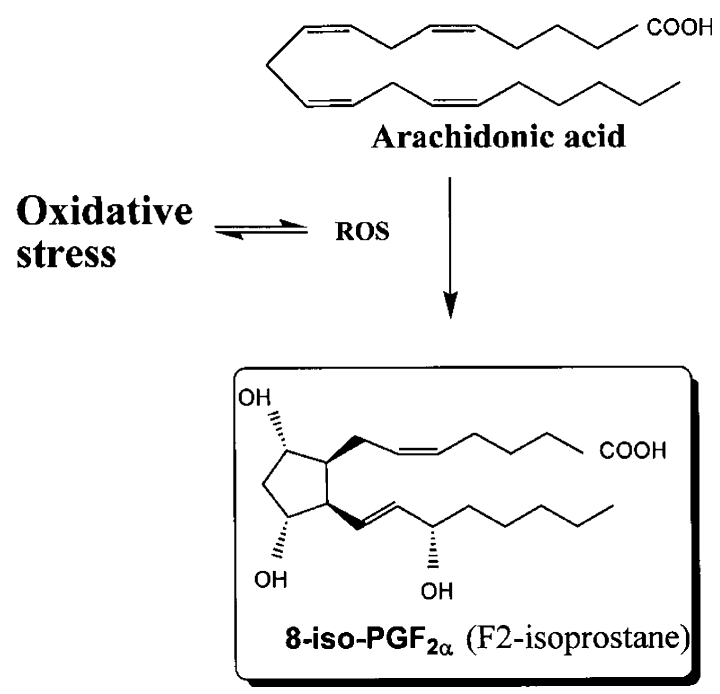

Fig. 2. Simplified scheme of 8-iso- $\mathrm{PGF}_{2 \alpha}$ ( $\mathrm{F}_{2}$-isoprostanes) formation from arachidonic acid by free radical catalysis. ROS: reactive oxygen species; PGF: prostaglandin F. 
for in situ localization of the compound by immunostaining of the oxidative stress-injured tissues. A novel study of such identification of oxidative stress-induced cytoplasm of neurons in Alzheimer's pathology has recently been described (23). This localization of bioactive isoprostanes by immunostaining with specific antibody is promising for further detection of free radical-mediated tissue damage in different diseases, and also offers possibilities for the detection of therapeutic effects of various radical scavengers in disease-related injuries.

Measuring malondialdehyde (MDA), the previously most commonly used measure of lipid peroxidation, is much less sensitive measuring than the increase in esterified isoprostanes in the liver (80- versus 2.7-fold) (24). Other comparative in vivo studies did not show any correlation between the increase in isoprostanes and MDA levels (25, 26). Very few studies have shown a correlation between protein oxidation and that of isoprostanes, mainly owing to the different character of these oxidative processes (radicals involved, timing, duration, cellular components, etc.). Even though measuring isoprostanes merely reflects the oxidation of arachidonic acid rather than of the total lipid pool, it is thought that other lipids might have also been oxidized in the process of lipid peroxidation. Additional advantages of measuring isoprostanes are that the levels of these compounds are not exaggerated by the lipid content of the diet (27). Nonetheless, it is vital to scrutinize when, what and which biological samples are preferential for measurement to avoid any risk of overlooking short- or long-lasting secretion of isoprostanes. Furthermore, incorrect collection, preservation and hazardous preparation (during extraction, purification and hydrolysis) of the samples before analysis are plausible factors in the artefactual formation of these compounds or impurity-affected analytical errors.

\section{The methodology for isoprostane analysis}

As already mentioned, measurements of MDA, thiobarbituric acid reactive substances (TBARS), lipid hydroperoxides, conjugated dienes, etc., have various methodological limitations $(2,28)$. Although gas chromatography and mass spectrometry (GCMS) were originally required for the detection and quantification of isoprostanes, other assay methods such as liquid chromatography (LC)-mass spectrometry, GC-MS-MS, LC-MS-MS, radioimmunoas- says and enzyme immunoassays $(1,29-31)$ are now also available. GC-MS-MS and LC-MS-MS methods require expensive and highly sensitive instruments to distinguish low levels of the compound in vivo, and well-trained technical staff, and sample preparation and characterization are complex. The more easily handled immunoassays are less specific and quantitative, unless antibodies are extensively confirmed for the cross-reactivities and other accuracy tests have been carried out. Nevertheless, immunoassays have been indispensable means for original innovation in the medical science since the early 1970s, which is also true for isoprostane analysis. A recent multilaboratory network study was organized by National Institute of Environmental Health Sciences (NIEHS), NIH, USA (BOSS-II and BOSS-III). Various oxidative stress biomarkers measured by different methods were used. The study showed that measurement of $\mathrm{F}_{2}$-isoprostanes in body fluids by different methods is indeed a consistent biomarker of in vivo oxidative stress $(32,33)$.

\section{Oxidative stress in vivo}

Carbon tetrachloride $\left(\mathrm{CCl}_{4}\right)$-induced oxidative stress is a conventional model in animals and has been used for decades (9). $\mathrm{CCl}_{4}$ introduced orally to experimental animals swiftly transforms to the trichloromethyl radical $\left(\cdot \mathrm{CCl}_{3}\right)$ or other radicals in the liver that subsequently induce in vivo oxidative stress. Measuring $\mathrm{F}_{2}$-isoprostanes using this model, also following administration of antioxidants such as vitamin $\mathrm{E}$, has been a most important tool in the evaluation of this biomarker of oxidative stress, as evidenced by several such studies $(21,22,25)$. A massive amount of esterified 8 -iso- $\mathrm{PGF}_{2 \alpha}$ was found in the liver tissues $2 \mathrm{~h}$ after the oral administration of $2.5 \mathrm{ml} \mathrm{kg}^{-1} \mathrm{CCl}_{4}$ to rats, whereas the free 8-iso- $\mathrm{PGF}_{2 \alpha}$ levels were quite low (19). In an additional study, it was shown that free 8-iso-PGF ${ }_{2 \alpha}$ levels increased 17 -fold in plasma and 53-fold in urine from the basal levels $4 \mathrm{~h}$ after $\mathrm{CCl}_{4}$ $\left(2 \mathrm{ml} \mathrm{kg}^{-1}\right)$ administration to rats (25). At $6 \mathrm{~h}$, free 8 -iso-PGF ${ }_{2 \alpha}$ levels in the plasma and urine had increased seven-fold in plasma and 87-fold in urine (Fig. 3). The levels of $F_{2}$-isoprostanes were still significantly elevated after 24 and $48 \mathrm{~h}$ compared with the baseline after the administration of $\mathrm{CCl}_{4}$ (22). The inhibitory effect of vitamin $\mathrm{E}$ or other antioxidants supported the theory that oxidative stress was involved in increasing the $\mathrm{F}_{2}$-isoprostanes upon $\mathrm{CCl}_{4}$ administration $(9,21,22)$. 

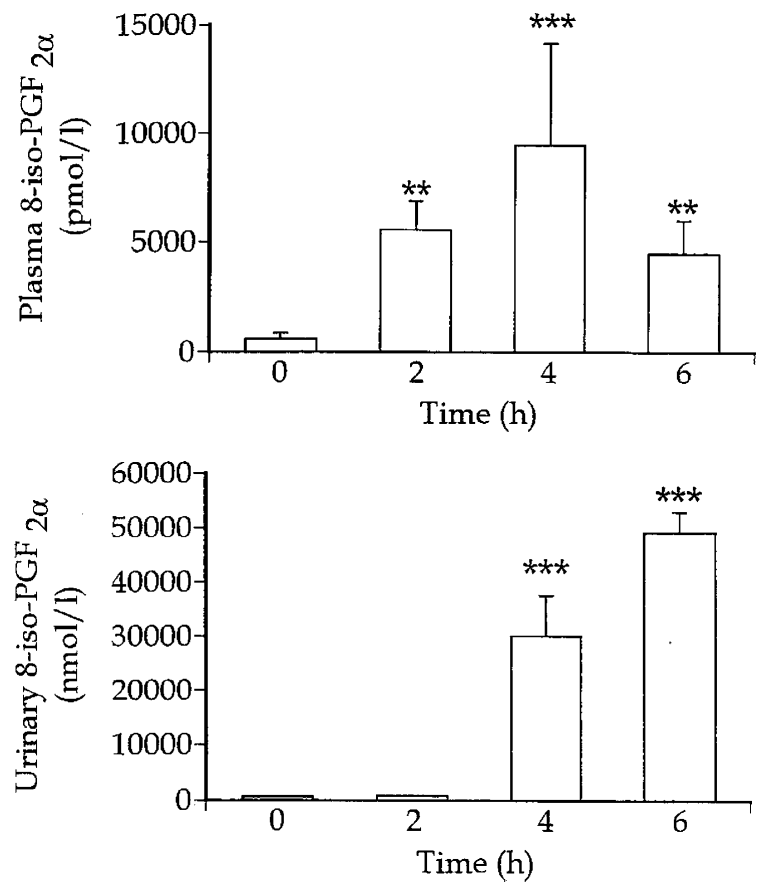

Fig. 3. Levels of free 8-iso-prostaglandin $F_{2 \alpha}\left(8\right.$-iso-PGF $\left.F_{2 \alpha}\right)$ in plasma and urine at different times after oral administration of $\mathrm{CCl}_{4}$ to rats $\left(2 \mathrm{ml} \mathrm{kg}{ }^{-1}\right)$. ${ }^{* * *} p<0.001,{ }^{* *} p<0.01$. [Reprinted with kind permission from Basu, 1999 (25)].

Ischaemia is the primary reason for tissue damage in, for example, cardiac infarction and stroke. It can be induced experimentally in laboratory animals (34). Reperfusion causes further local and remote organ damage that is frequently observed in intensive care units. Free radical formation at the location of injury is involved in this process, which subsequently induces oxidative stress in the whole body (35). In a well-established experimental porcine model, oxidative injury was assessed by the measurement of 8 -iso- $\mathrm{PGF}_{2 \alpha}$ in plasma samples collected from both systemic circulation and the jugular bulb, which mainly drains the brain, 2 and 5 min after cardiac arrest (36). 8-Iso-PGF $2 \alpha$ increased rapidly in both in the systemic circulation (Fig. 4, upper panel) and jugular bulb plasma (Fig. 4 , lower panel) at both time-points. In two additional studies with increased time of cardiac arrest ( $8 \mathrm{~min}$ of ventricular fibrillation) it was shown that 8 -iso- $\mathrm{PGF}_{2 \alpha}$ levels increased in jugular bulb plasma concomitant with increases in the levels of a COX-mediated $\mathrm{PGF}_{2 \alpha}$ metabolite, hypoxanthine, and lactate $(37,38)$. A further increase in cardiac arrest time (up to $12 \mathrm{~min}$ of ventricular fibrillation) led to an additional increase in 8 -iso- $\mathrm{PGF}_{2 \alpha}$ in the jugular bulb plasma (35). In addition, the levels of plasma 8-iso-PGF $2 \alpha$ correlated with the neurologi- cal score of the experimental animals at $24 \mathrm{~h}$ following cardiac arrest and resuscitation (37). Similarly, increased formation of $\mathrm{F}_{2}$-isoprostanes following experimental cardiac arrest and resuscitation has recently been found in brain tissue (39). The rapid appearance of 8 -iso- $\mathrm{PGF}_{2 \alpha}$ in the plasma and urine was also observed during ischaemiareperfusion in experimental spinal cord ischaemia in pigs (40) and canine models (41).

Taken together, these studies support the concept that $\mathrm{F}_{2}$-isoprostanes not only increase in models of ischaemia-reperfusion, but also play a bioactive role in the consequences of this injury. The increase in $\mathrm{F}_{2}$-isoprostanes in the brain could be counteracted by the administration of various radical scavengers such as $\alpha$-phenyl- $N$-tert-butyl nitrone (PBN), sulfonated $\alpha$-phenyl- $N$-tert-butyl nitrone (S-PBN) and methylene blue, which further supports the theory that oxidative stress is involved in ischaemia-reperfusion injury $(37,38,42)$.

\section{Isoprostanes in other human diseases}

Table 1 shows a comprehensive list of diseases where isoprostanes have been measured, and this list is growing progressively. Elevated levels in smokers were an early indication of the involvement of isoprostanes (68) and this has been corroborated in several other studies $(69,111)$. Increased, but less elevated levels of $\mathrm{F}_{2}$-isoprostanes have also been demonstrated in former smokers (69).

Major controversies in this field remain over whether isoprostanes are implicated in Alzheimer's disease and type 1 diabetes. In Alzheimer's diseases, increased levels of $F_{2}$-isoprostanes have been found specifically in the cerebrospinal fluid, neurons and brain tissues $(23,89,90,112,113)$. One study also demonstrated increased levels in the urine and plasma (91), which was not confirmed in other studies $(93,114)$. The reason for this inconsistency may be that biological samples were not taken at identical stages of the disease or that different drugs embroidered the outcome. The majority of the studies with Alzheimer's disease have revealed that increased formation of isoprostanes is seen mainly in neuronal tissues or in the cerebrospinal fluid.

Concerning type 1 diabetes, one report described an elevated level of 8 -iso- $\mathrm{PGF}_{2 \alpha}$ in urine from patients with type 1 diabetes (43). However, a number of other reports showed no such differences in patients with type 1 diabetes compared with controls (Table 1) (44-48). Young Swedish patients 

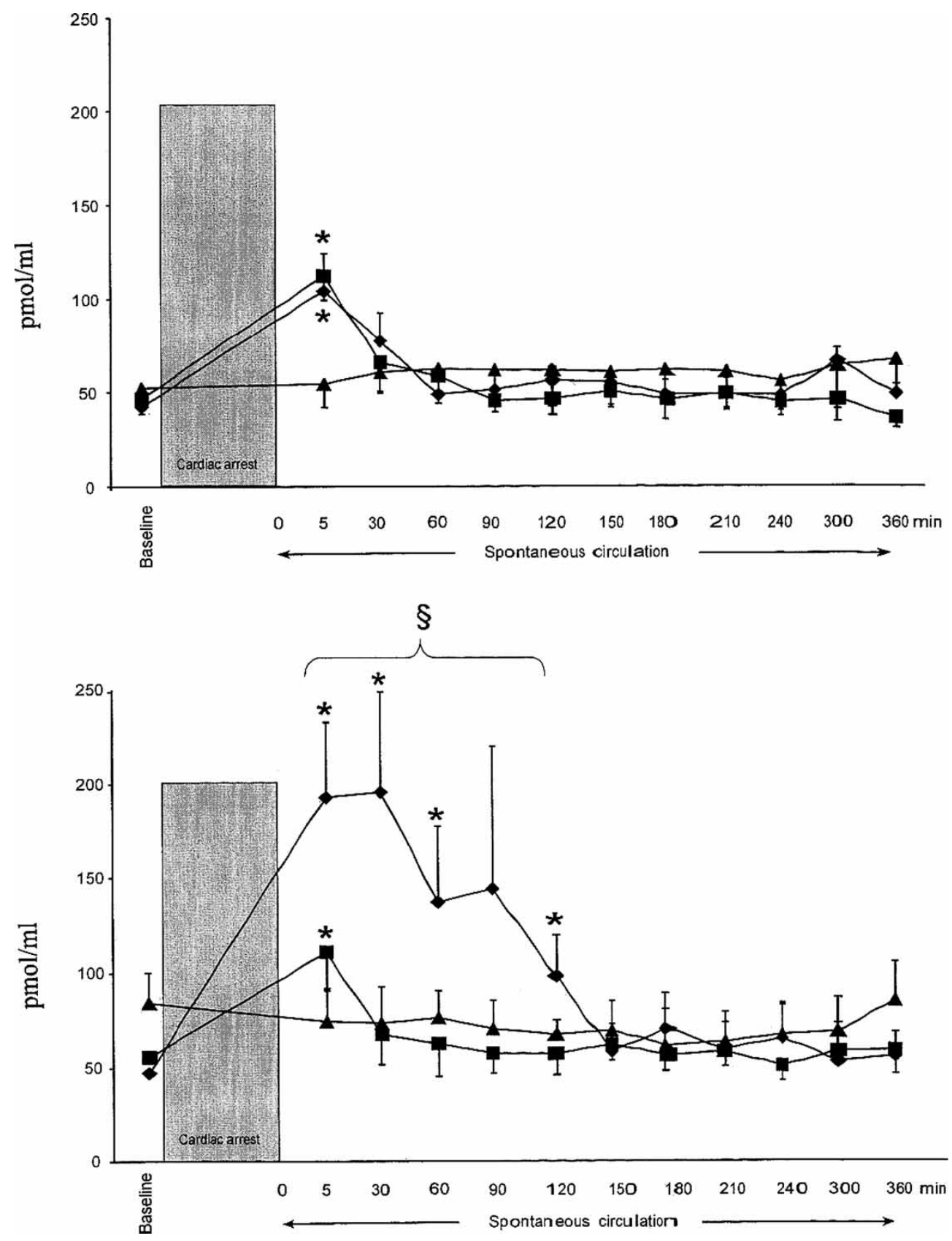

Fig. 4. Upper panel: Mixed venous plasma levels of 8-iso-prostaglandin $F_{2 \alpha}\left(8\right.$-iso- $\left.P_{G F}\right)$ at baseline and after restoration of spontaneous circulation (ROSC). Lower panel: Jugular bulb plasma levels of 8-iso-PGF $2 \alpha$ at baseline and after ROSC. : Group ventricular fibrillation (VF) 5; $\mathbf{\square}$ : group VF2; $\mathbf{\Lambda}$ : control group. *: Significant difference versus baseline; §: significant difference between group VF5 versus other groups. Values are expressed as means \pm SEM. [Reprinted with permission from Basu et al., 2000 (36)].

with type 1 diabetes had no increase in 8 -iso- $\mathrm{PGF}_{2 \alpha}$ concentrations compared with matched controls (46). Similarly, there was no increase in the urinary 2,3-dinor-5,6-dihydro metabolite of 8-iso- $\mathrm{PGF}_{2 \alpha}$ in type 1 diabetes (45). However, one study showed increased levels of 8 -iso- $\mathrm{PGF}_{2 \alpha}$ in the early phase of diabetes onset and the level was stabilized after 1 year, in conjunction with control of the metabolic status (44). Thus, it is assumed that differences in the metabolic control in terms of $\mathrm{HbA}_{1 \mathrm{C}}$ and fasting glucose, hyperlipidaemia or degree of vascular damage consecutively affect the degree of lipid peroxidation and oxidative stress. The role of isoprostanes in other areas, e.g. osteoporosis, is unclear. However, it has been shown that urinary levels of 8 -iso- $\mathrm{PGF}_{2 \alpha}$ are related to bone mineral density in humans, indicating that oxidative stress might be involved also in osteoporosis (115). 
Table I. $\mathrm{F}_{2}$-Isoprostanes in human physiology and pathology

\begin{tabular}{|c|c|c|}
\hline Pathological condition & Selected references & Observations \\
\hline \multicolumn{3}{|l|}{ Diabetes } \\
\hline \multirow[t]{4}{*}{ Type I diabetes } & Davi $(43,44)$ & Elevated \\
\hline & O’Byrne (45) & Did not differ \\
\hline & Vessby (46) & Did not differ \\
\hline & Hoeldtke (47) & Did not differ \\
\hline \multirow[t]{5}{*}{ Type 2 diabetes } & Gopaul $(49,50)$ & Elevated \\
\hline & Davi (43) & Elevated \\
\hline & Murai (5I) & Elevated \\
\hline & Helmersson (52) (elderly & Elevated \\
\hline & men $>7$ years' disease duration) & \\
\hline \multicolumn{3}{|l|}{ Metabolic syndrome/lipid metabolism } \\
\hline & Reilly (54) & Elevated \\
\hline & Roberts (55) & Elevated \\
\hline & Raal (56) & Did not differ \\
\hline Type Ila hypercholesterolaemia & Cracowski (57) & Did not differ \\
\hline \multicolumn{3}{|l|}{ Cardiovascular diseases } \\
\hline \multirow[t]{3}{*}{ Atherosclerosis } & Pratico (58) & Elevated \\
\hline & Gniwotta (59) & Elevated \\
\hline & Mehrabi (60) & Elevated \\
\hline \multirow[t]{2}{*}{ Cardiopulmonary bypass } & Ulus (6I) & Elevated \\
\hline & Delanty (4I) & Elevated \\
\hline \multirow{3}{*}{$\begin{array}{l}\text { Coronary reperfusion/angioplasty/ } \\
\text { percutaneous coronary intervention }\end{array}$} & Reilly (62) & Elevated \\
\hline & & \\
\hline & Berg (63) & Elevated \\
\hline Angiography & Berg (63) & Elevated \\
\hline Coronary artery disease & Shishehbor (65) & Elevated \\
\hline \multirow[t]{2}{*}{ Heart failure } & Cracowski (66) & Elevated \\
\hline & Mallat (67) & Elevated \\
\hline \multicolumn{3}{|l|}{ Cardiovascular risk factors } \\
\hline \multirow[t]{2}{*}{ Smoking } & Morrow (68) & Elevated \\
\hline & Helmersson (69) & Elevated \\
\hline Passive smoking & Ahmadzadehfar (70) & Elevated \\
\hline Former smokers & Helmersson (69) & Elevated \\
\hline \multicolumn{3}{|l|}{ Pulmonary diseases } \\
\hline \multirow[t]{3}{*}{ Asthma } & Montuschi (7I) & Elevated \\
\hline & Wood (72) & Elevated \\
\hline & Baraldi (73) & Elevated \\
\hline Acute respiratory distress syndrome & Carpenter (74) & Elevated \\
\hline \multirow[t]{3}{*}{ Cystic fibrosis } & Collins (75) & Elevated \\
\hline & Ciabattoni (76) & Elevated \\
\hline & Montuschi (77) & Elevated \\
\hline Pulmonary hypertension & Cracowski (78) & Elevated \\
\hline \multirow[t]{2}{*}{ Obstructive pulmonary diseases } & Pratico (79) & Elevated \\
\hline & Montuschi (80) & Elevated \\
\hline Interstitial lung diseases & Montuschi (8I) & Elevated \\
\hline \multicolumn{3}{|l|}{ Reproductive diseases } \\
\hline \multirow[t]{4}{*}{ Pre-eclampsia } & Morris (82) & Did not differ \\
\hline & Ishihara (83) & Did not differ \\
\hline & Regan (84) & Did not differ \\
\hline & Walsh (85) & Elevated \\
\hline
\end{tabular}




\begin{tabular}{|c|c|c|}
\hline Pathological condition & Selected references & Observations \\
\hline Pregnancy with Down's syndrome & Perrone (88) & Elevated \\
\hline \multicolumn{3}{|l|}{ Neurodegenerative diseases } \\
\hline \multirow[t]{5}{*}{ Alzheimer's disease } & Montine $(89,90)$ & Elevated \\
\hline & Pratico (91) & Elevated \\
\hline & Feillet-Coudray (92) & Did not differ \\
\hline & Montine $(93,94)$ & Did not differ \\
\hline & Casadesus (23) & Differed \\
\hline \multirow[t]{2}{*}{ Huntington's disease } & Montine (94) & Did not differ \\
\hline & Montine (95) & Elevated \\
\hline Parkinson's diseases & Fessel (96) & Did not differ \\
\hline Dementia with Lewy body disease & Fessel (96) & Did not differ \\
\hline Migraine & Helmersson (97) & Did not differ \\
\hline Spinal cord injury & Monga (98) & Elevated \\
\hline Multiple sclerosis & Mattsson (99) & Elevated \\
\hline \multicolumn{3}{|l|}{ Other diseases } \\
\hline Prostate cancer & Camphausen (100) & Did not differ \\
\hline \multirow[t]{2}{*}{ Haemodialysis } & Handelman (I0I) & Elevated \\
\hline & Ikizler (102) & Elevated \\
\hline \multirow[t]{2}{*}{ Kidney transplantation } & Cracowski (103) & Did not differ \\
\hline & Basu (104) & Elevated \\
\hline Dialysis patients & Lauzurica (105) & Elevated \\
\hline Hypertension with renovascular disease & Minuz (106) & Elevated \\
\hline \multicolumn{3}{|l|}{ Inflammatory diseases } \\
\hline Rheumatoid arthritis & Basu (107) & Elevated \\
\hline Psoriatic arthritis & Basu (107) & Elevated \\
\hline Reactive arthritis & Basu (107) & Elevated \\
\hline Osteoarthritis & Basu (107) & Elevated \\
\hline \multirow[t]{2}{*}{ Systemic sclerosis } & Cracowski (108) & Elevated \\
\hline & Stein (109) & Elevated \\
\hline Periodontal disease & Wolfram (I I0) & Elevated \\
\hline \multicolumn{3}{|l|}{ Physiological conditions } \\
\hline \multirow[t]{2}{*}{ Human pregnancy } & Morris (82) & Elevated \\
\hline & Ishihara (83) & Elevated \\
\hline
\end{tabular}

\section{Foreword theory of oxidative strain compared with oxidative stress}

In healthy aerobic organisms, the formation of reactive radical species of diverse activity appears to be finely tuned by the body's efficient antioxidant defence system. Nonetheless, once the production exceeds the regular physiological equilibrium, the mammalian body experiences potentially deleteriously distress, frequently referred to as oxidative stress. It is rarely described whether mild or low grade oxidative stress has any function in physiology, apart from being seen in chronic diseases such as diabetes, obesity and atherosclerosis, and also in smoking. Moderately higher levels of isoprostanes are seen in these conditions, compared with the more pronounced response seen in acute inflammatory situations.
It seems now that a mild increase in basal isoprostanes is also a component of certain basic physiological states such as normal pregnancy (82, 83). When an increased oxidative activity occurs as part of a normal physiological state, it may be considered as an "oxidative strain" rather than an oxidative stress. In other words, oxidative strain could be regarded as a condition in which increased free radical-mediated reactions are necessary to maintain specific functions. In such specific circumstances, the body requires a mild oxidative imbalance. This situation is different from the chronic low-grade inflammatory conditions in chronic diseases, where a low but sustained increase in $\mathrm{F}_{2}$-isoprostanes occurs $(52,69,116)$, or the high increase in $F_{2}$-isoprostanes seen in chronic severe inflammatory conditions, such as rheumatic 
diseases, asthma or acute respiratory distress syndrome (ARDS) $(71,77,81,107)$.

\section{Role of antioxidants on isoprostane formation}

A central issue remaining to be elucidated is the role of exogenous antioxidants in different human diseases where oxidative stress is involved in the pathology. This issue can be addressed indirectly by studies of effects on reliable oxidative stress biomarkers such as isoprostanes. In rats with $\mathrm{CCl}_{4}$ induced hepatotoxicity, a high dose of vitamin $\mathrm{E}$ $\left(20 \mathrm{~g} \mathrm{~kg}^{-1}\right.$ diet of all-rac-tocopheryl succinate for 3 weeks) affected non-enzymic lipid peroxidation (21). Administration of vitamin $\mathrm{E}$ before the $\mathrm{CCl}_{4}$ treatment resulted in significantly lower levels of urinary and liver free 8-iso- $\mathrm{PGF}_{2 \alpha}$. Thus, lipid peroxidation during experimental hepatic oxidative injury and inflammatory response could be reduced by daily dietary supplementation of high doses of vitamin E. It has also been shown that antioxidant therapy ameliorated the progression of atherosclerosis and isoprostane formation in animal studies (117).

Recent human studies, however, show that $\alpha$ tocopherol in varying doses (200-2000 IU per day for 8 weeks or 200 IU per day for 2 weeks) did not affect the concentrations of $F_{2}$-isoprostanes (118, 119). Vitamin E supplementation also did not affect levels of $\mathrm{F}_{2}$-isoprostanes in moderate cigarette smokers (120). In another study in which cigarette smokers consumed a diet high in polyunsaturated fat a pro-oxidant effect of supplementary vitamin $\mathrm{E}$ was even observed (121). However, when hypercholesterolaemic patients were treated with high doses (800-3200 IU per day), but not with lower doses (100-400 IU per day) of vitamin E, a significant decrease in the plasma $F_{2}$-isoprostane level was noted after 16 weeks (55), as seen in the animal studies (21). Other studies, however, have shown that vitamin E supplementation reduced the urinary concentration of $\mathrm{F}_{2}$-isoprostanes in patients with type 2 diabetes (43), cystic fibrosis (76), hypercholesterolaemia (53) and homozygous homocystinuria (122), and also reduced urinary $F_{2}$-isoprostane levels in hepatic cirrhosis and alcoholic liver disease (123).

In a mechanistic study in which the formation of different isomers of CLA-induced $\mathrm{F}_{2}$-isoprostanes was followed in healthy subjects, no decrease in the urinary 8 -iso-PGF ${ }_{2 \alpha}$ level was seen during 4 weeks of supplementation with vitamin E (200 IU per day)
(119). Neither did 28 days' supplementation with various doses of $\alpha$-tocopherol (15, 100, 200 and 400 IU per day) have any effect on the basal levels of $\mathrm{F}_{2}$-isoprostanes in healthy human subjects (124). Together, these studies show that vitamin E supplementation has a varying antioxidative effect in studies related to different doses or patients or population groups or stage of pathogenesis of diseases, possibly depending on the basal lipid peroxidation process or even the pharmacogenomics in these individuals. Measurement of isoprostanes would be a relevant tool in the further study of the efficacy of various antioxidants.

Oxidative modification of low-density lipoproteins and the subsequent formation of foam cells are considered to affect the formation of atherosclerotic lesions, and both in vitro and various experimental studies show that oxidative stress is involved in all stages of coronary artery disease (125-128). However, recent large clinical trials have failed to demonstrate any clinical outcome of antioxidant supplementation (129). This is possibly due to the fact that the majority of these intervention studies neither had any reliable way of determining systemic oxidant stress, nor recruited the patients according to degree of oxidant stress. More studies are needed to prove or refute the role of antioxidant therapy in atherosclerosis. The most momentous question in this context is whether this disease is caused by oxidative stress or whether oxidative stress is merely a consequence of other disease processes.

\section{Conclusions}

Oxidative stress is believed to be one of the major processes underlying several acute or chronic diseases. Isoprostanes are biologically potent free radical-catalysed compounds, and current evidence suggests that they are reliable in vivo biomarkers of oxidative stress. Isoprostanes are involved in normal physiology such as human pregnancy, as well as in acute and chronic inflammation pathology. These non-enzymically, rapidly formed compounds not only are bioactive themselves, but also seem to be useful as novel early biomarkers of oxidative stress, and further could be applied to study the efficacy of antioxidants and other free radical scavengers.

\section{References}

1. Morrow JD, Hill KE, Burk RF, Nammour TM, Badr KF, Roberts LJd. A series of prostaglandin F2-like 
compounds are produced in vivo in humans by a noncyclooxygenase, free radical-catalyzed mechanism. Proc Natl Acad Sci USA 1990; 87: 9383-7.

2. Roberts LJ, Morrow JD. Measurement of $F_{2}$-isoprostanes as an index of oxidative stress in vivo. Free Radic Biol Med 2000; 28: 505-13.

3. Basu S. $\mathrm{F}_{2}$-isoprostane induced prostaglandin formation in the rabbit. Free Radic Res 2006; 40: 273-7.

4. Basu S. Isoprostanes: novel bioactive products of lipid peroxidation. Free Radic Res 2004; 38: 105-22.

5. Samuelsson B, Dahlen SE, Lindgren JA, Rouzer CA, Serhan CN. Leukotrienes and lipoxins: structures, biosynthesis, and biological effects. Science 1987; 237: 1171-6.

6. Serhan CN. Novel eicosanoid and docosanoid mediators: resolvins, docosatrienes, and neuroprotectins. Curr Opin Clin Nutr Metab Care 2005; 8: 115-21.

7. Basu S. Novel cyclooxygenase-catalysed bioactive prostaglandin $\mathrm{F}_{2 \alpha}$ from physiology to new principles in inflammation. Medicinal Research Reviews 2006; On-line published December 2006.

8. Halliwell B, Chirico S. Lipid peroxidation: its mechanism, measurement, and significance. Am J Clin Nutr 1993;57:715-24S; discussion 724-5S.

9. Basu S. Carbon tetrachloride-induced lipid peroxidation: eicosanoid formation and their regulation by antioxidant nutrients. Toxicology 2003; 189: 113-27.

10. Finkel T, Holbrook NJ. Oxidants, oxidative stress and the biology of ageing. Nature 2000; 408: 239-47.

11. Finkel T. Oxygen radicals and signaling. Curr Opin Cell Biol 1998; 10: 248-53.

12. Nishikawa $T$, Edelstein $\mathrm{D}, \mathrm{Du} \mathrm{XL}$, Matsumaura $\mathrm{T}$, Kaneda Y, Yorek MA. Normalizing mitochondrial superoxide production blocks three pathways of hyperglycaemic damage. Nature 2000; 404: 787-90.

13. Bogdan C. Nitric oxide and the regulation of gene expression. Trends Cell Biol 2001; 11: 66-75.

14. Nemoto S, Finkel T. Ageing and the mystery at Arles. Nature 2004; 429: 149-52.

15. Nugteren DH, Vonkeman H, van Dorf DA. Nonenzymatic conversion of all cis 8,11,14-eicosapentanoic acid into $\mathrm{PGE}_{1}$. Recl Trav Chim Pays-bas 1967; 86: 1237-45.

16. Porter NA, Funk MO. Letter: Peroxy radical cyclization as a model for prostaglandin biosynthesis. J Org Chem 1975; 40: 3614-5.

17. Morrow JD. The isoprostanes: their quantification as an index of oxidant stress status in vivo. Drug Metab Rev 2000; 32: 377-85.

18. Morrow JD, Awad JA, Boss HJ, Blair IA, Roberts LJ II. Non-cyclooxygenase-derived prostanoids $\left(\mathrm{F}_{2}\right.$-isoprostanes) are formed in situ on phospholipids. Proc Natl Acad Sci USA 1992; 89: 10721-5.

19. Sodergren E, Vessby B, Basu S. Radioimmunological measurement of $\mathrm{F}_{2}$-isoprostanes after hydrolysis of lipids in tissues. Prostaglandins Leukot Essent Fatty Acids 2000; 63: 149-52.

20. Basu S, Helmersson J. Factors regulating isoprostane formation in vivo. Antioxid Redox Signal 2005; 7: $221-$ 35 .
21. Sodergren E, Cederberg J, Vessby B, Basu S. Vitamin E reduces lipid peroxidation in experimental hepatotoxicity in rats. Eur J Nutr 2001; 40: 10-6.

22. Morrow JD, Awad JA, Kato T, Takahashi K, Badr KF, Roberts LJ. Formation of novel non-cyclooxygenasederived prostanoids ( $\mathrm{F}_{2}$-isoprostanes) in carbon tetrachloride hepatotoxicity. An animal model of lipid peroxidation. J Clin Invest 1992; 90: 2502-7.

23. Casadesus G, Smith MA, Basu S, Hua J, Capobianco $\mathrm{DE}$, Siedlak S. Increased isoprostane and prostaglandin are prominent in neurons in Alzheimer disease. Mol Neurodegener 2007; 2: 2.

24. Longmire AW, Swift LL, Roberts LJ II, Awad JA, Burk RF, Morrow JD. Effect of oxygen tension on the generation of $\mathrm{F}_{2}$-isoprostanes and malondialdehyde in peroxidizing rat liver microsomes. Biochem Pharmacol 1994; 47: 1173-7.

25. Basu S. Oxidative injury induced cyclooxygenase activation in experimental hepatotoxicity. Biochem Biophys Res Commun 1999; 254: 764-7.

26. Hart CM, Karman RJ, Blackburn TL, Gupta MP, Garcia JG, Mohler ER III. Role of 8-epi $\mathrm{PGF}_{2 \alpha}$, 8isoprostane, in $\mathrm{H}_{2} \mathrm{O}_{2}$-induced derangements of pulmonary artery endothelial cell barrier function. Prostaglandins Leukot Essent Fatty Acids 1998; 58: 9-16.

27. Richelle M, Turini ME, Guidoux R, Tavazzi I, Metairon S, Fay LB. Urinary isoprostane excretion is not confounded by the lipid content of the diet. FEBS Lett 1999; 459: 259-62.

28. Halliwell B. Lipid peroxidation, antioxidants and cardiovascular disease: how should we move forward? Cardiovasc Res 2000; 47: 410-8.

29. Basu S. Radioimmunoassay of 8-iso-prostaglandin $F_{2 \alpha}$ : an index for oxidative injury via free radical catalysed lipid peroxidation. Prostaglandins Leukot Essent Fatty Acids 1998; 58: 319-25.

30. Wang Z, Ciabattoni G, Creminon C, Lawson J, FitzGerald GA, Patrono C. Immunological characterization of urinary 8-epi-prostaglandin $\mathrm{F}_{2 \alpha}$ excretion in man. J Pharmacol Exp Ther 1995; 275: 94-100.

31. Adiyaman M, Lawson JA, Khanapure SP, FitzGerald GA, Rokach J. Total synthesis of 17,17,18,18-d4-iPF $2 \alpha^{-}$ VI and quantification of $\mathrm{PPF}_{2 \alpha}$-VI in human urine by gas chromatography/mass spectrometry. Anal Biochem 1998; 262: 45-56.

32. Kadiiska MB, Gladen BC, Baird DD, Germolec D, Graham LB, Parker CE. Biomarkers of oxidative stress study II: are oxidation products of lipids, proteins, and DNA markers of $\mathrm{CCl} 4$ poisoning? Free Radic Biol Med 2005; 38: 698-710.

33. Kadiiska MB, Gladen BC, Baird DD, Graham LB, Parker CE, Ames BN. Biomarkers of oxidative stress study III. Effects of the nonsteroidal anti-inflammatory agents indomethacin and meclofenamic acid on measurements of oxidative products of lipids in $\mathrm{CCl}_{4}$ poisoning. Free Radic Biol Med 2005; 38: 711-8.

34. Wiklund L, Sharma HS, Basu S. Circulatory arrest as a model for studies of global ischemic injury and neuroprotection. Ann N Y Acad Sci 2005; 1053: 20519. 
35. Basu S, Liu X, Nozari A, Rubertsson S, Miclescu A, Wiklund L. Evidence for time-dependent maximum increase of free radical damage and eicosanoid formation in the brain as related to duration of cardiac arrest and cardio-pulmonary resuscitation. Free Radic Res 2003; 37: 251-6.

36. Basu S, Nozari A, Liu XL, Rubertsson S, Wiklund L. Development of a novel biomarker of free radical damage in reperfusion injury after cardiac arrest. FEBS Lett 2000; 470: 1-6.

37. Liu XL, Nozari A, Basu S, Ronquist G, Rubertsson S, Wiklund L. Neurological outcome after experimental cardiopulmonary resuscitation: a result of delayed and potentially treatable neuronal injury? Acta Anaesthesiol Scand 2002; 46: 537-46.

38. Liu XL, Wiklund L, Nozari A, Rubertsson S, Basu S. Differences in cerebral reperfusion and oxidative injury after cardiac arrest in pigs. Acta Anaesthesiol Scand 2003; 47: 958-67.

39. Idris AH, Roberts LJ II, Caruso L, Showstark M, Layon AJ, Becker LB, et al. Oxidant injury occurs rapidly after cardiac arrest, cardiopulmonary resuscitation, and reperfusion. Crit Care Med 2005; 33: 2043-8.

40. Basu S, Hellberg A, Ulus AT, Westman J, Karacagil S. Biomarkers of free radical injury during spinal cord ischemia. FEBS Lett 2001; 508: 36-8.

41. Delanty N, Reilly MP, Pratico D, Mezzetti A, Falco A, Santarone S. 8-epi $\mathrm{PGF}_{2}$ alpha generation during coronary reperfusion. A potential quantitative marker of oxidant stress in vivo. Circulation 1997; 95: 2492-9.

42. Miclescu A, Basu S, Wiklund L. Methylene blue added to hypertonic-hyperoncotic solution increases survival in experimental cardiac arrest. Crit Care Med 2006; 34: 2806-16.

43. Davi G, Ciabattoni G, Consoli A, Lawson JA, McCarthy JF, Wood AE. In vivo formation of 8-isoprostaglandin $\mathrm{F}_{2 \alpha}$ and platelet activation in diabetes mellitus: effects of improved metabolic control and vitamin E supplementation. Circulation 1999; 99: 224 9.

44. Davi G, Chiarelli F, Santilli F, Pomilio M, Vigneri S, Falco A. Enhanced lipid peroxidation and platelet activation in the early phase of type 1 diabetes mellitus: role of interleukin-6 and disease duration. Circulation 2003; 107: 3199-203.

45. O'Byrne S, Forte P, Roberts LJ II, et al. Nitric oxide synthesis and isoprostane production in subjects with type 1 diabetes and normal urinary albumin excretion. Diabetes 2000; 49: 857-62.

46. Vessby J, Basu S, Mohsen R, Berne C, Vessby B. Oxidative stress and antioxidant status in type 1 diabetes mellitus. J Intern Med 2002; 251: 69-76.

47. Hoeldtke RD, Bryner KD, McNeill DR, Warehime SS, Van Dyke K, Hobbs G. Oxidative stress and insulin requirements in patients with recent-onset type 1 diabetes. J Clin Endocrinol Metab 2003; 88: 1624-8.

48. Gleisner A, Martinez L, Pino R, Rojas IG, Martinez A, Asenjo S. Oxidative stress markers in plasma and urine of prepubertal patients with type 1 diabetes mellitus. J Pediatr Endocrinol Metab 2006; 19: 995-1000.
49. Gopaul NK, Anggard EE, Mallet AI, Betteridge DJ, Wolff SP, Nourooz-Zadeh J. Plasma 8-epi-PGF ${ }_{2 \alpha}$ levels are elevated in individuals with non-insulin dependent diabetes mellitus. FEBS Lett 1995; 368: 225-9.

50. Gopaul NK, Manraj MD, Hebe A, Lee Kwai Yan S, Jonston A, Carrier MJ. Oxidative stress could precede endothelial dysfunction and insulin resistance in Indian Mauritians with impaired glucose metabolism. Diabetologia 2001; 44: 706-12.

51. Murai Y, Hishinuma T, Suzuki N, Satoh J, Toyota T, Mizugaki M. Determination of urinary 8-epi-prostaglandin $F_{2 \alpha}$ using liquid chromatography-tandem mass spectrometry: increased excretion in diabetics. Prostaglandins Other Lipid Mediat 2000; 62: 173-81.

52. Helmersson J, Vessby B, Larsson A, Basu S. Association of type 2 diabetes with cyclooxygenase-mediated inflammation and oxidative stress in an elderly population. Circulation 2004; 109: 1729-34.

53. Davi G, Alessandrini P, Mezzetti A, Minotti G, Bucciarelli $\mathrm{T}$, Costantini F. In vivo formation of 8-epi-prostaglandin $\mathrm{F}_{2 \alpha}$ is increased in hypercholesterolemia. Arterioscler Thromb Vasc Biol 1997; 17: 32305 .

54. Reilly MP, Pratico D, Delanty N, Dimmino G, Tremoli E, Rader D. Increased formation of distinct $\mathrm{F}_{2}$ isoprostanes in hypercholesterolemia. Circulation 1998; 98: 2822-8.

55. Roberts LJ, Oates JA, Fazio S, Gross M, Linton M, Morrow J. A-tocopherol supplementation reduces plasma $\mathrm{F}_{2}$-isoprostane concentrations in hypercholesterolemic humans only at doses of $800 \mathrm{IU}$ or higher. Free Radic Biol Med 2002; 33: S412.

56. Raal FJ, Pilcher GJ, Waisberg R, Buthelezi EP, Veller MG, Joffe BI. Low-density lipoprotein cholesterol bulk is the pivotal determinant of atherosclerosis in familial hypercholesterolemia. Am J Cardiol 1999; 83: 1330-3.

57. Cracowski JL, Ploin D, Bessard J, Braguet JP, StankeLabesque F, Mallion JM. Formation of isoprostanes in children with type IIa hypercholesterolemia. J Cardiovasc Pharmacol 2001; 38: 228-31.

58. Pratico D, Iuliano L, Mauriello A, Spaqnoli L, Lawson JA, Rokach J. Localization of distinct $\mathrm{F}_{2}$-isoprostanes in human atherosclerotic lesions. J Clin Invest 1997; 100: $2028-34$.

59. Gniwotta C, Morrow JD, Roberts LJ II, Kuhn H. Prostaglandin $\mathrm{F}_{2}$-like compounds, $\mathrm{F}_{2}$-isoprostanes, are present in increased amounts in human atherosclerotic lesions. Arterioscler Thromb Vasc Biol 1997; 17: 3236 41.

60. Mehrabi MR, Ekmekcioglu C, Tatzber F, Oquogho A, Ullrich A, Morgan A. The isoprostane, 8-epi-PGF $2 \alpha$, is accumulated in coronary arteries isolated from patients with coronary heart disease. Cardiovasc Res 1999; 43: 492-9.

61. Ulus AT, Aksoyek A, Ozkan M, Katircioglu SF, Basu S. Cardiopulmonary bypass as a cause of free radicalinduced oxidative stress and enhanced blood-borne isoprostanes in humans. Free Radic Biol Med 2003; 34: 911-7. 
62. Reilly MP, Delanty N, Roy L, Rokach J, Callaghan PO, Crean $\mathrm{P}$, et al. Increased formation of the isoprostanes $\mathrm{IPF}_{2 \alpha}-\mathrm{I}$ and 8-epi-prostaglandin $\mathrm{F}_{2 \alpha}$ in acute coronary angioplasty: evidence for oxidant stress during coronary reperfusion in humans. Circulation 1997; 96: 3314 20.

63. Berg K, Wiseth R, Bjerve K, Brurok H, Gunnes S, Skara S. Oxidative stress and myocardial damage during elective percutaneous coronary interventions and coronary angiography. A comparison of bloodborne isoprostane and troponin release. Free Radic Res 2004; 38: 517-25.

64. Iuliano L, Pratico D, Greco C, Mangichi E, Scibillia G, FitzGerald GA. Angioplasty increases coronary sinus $\mathrm{F}_{2}$-isoprostane formation: evidence for in vivo oxidative stress during PTCA. J Am Coll Cardiol 2001; 37: $76-80$.

65. Shishehbor MH, Zhang R, Medina H, Brennan ML, Brennan DM, Ellis SG. Systemic elevations of free radical oxidation products of arachidonic acid are associated with angiographic evidence of coronary artery disease. Free Radic Biol Med 2006; 41: 1678-83.

66. Cracowski JL, Tremel F, Marpeau C, et al. Increased formation of $\mathrm{F}_{2}$-isoprostanes in patients with severe heart failure. Heart 2000; 84: 439-40.

67. Mallat Z, Philip I, Lebret M, Chatel D, Maclouf J, Tedgui A. Elevated levels of 8-iso-prostaglandin $\mathrm{F}_{2 \alpha}$ in pericardial fluid of patients with heart failure: a potential role for in vivo oxidant stress in ventricular dilatation and progression to heart failure. Circulation 1998; 97: 1536-9.

68. Morrow JD, Frei B, Longmire AW, Gaziano JM, Lynch SM, Shyr Y. Increase in circulating products of lipid peroxidation ( $\mathrm{F}_{2}$-isoprostanes) in smokers. Smoking as a cause of oxidative damage. N Engl J Med 1995; 332: 1198-203.

69. Helmersson J, Larsson A, Vessby B, Basu S. Active smoking and a history of smoking are associated with enhanced prostaglandin $F_{2 \alpha}$, interleukin- 6 and $F_{2}$ isoprostane formation in elderly men. Atherosclerosis 2005; 181: 201-7.

70. Ahmadzadehfar H, Oguogho A, Efthimiou Y, Kritz H, Sinzinger H. Passive cigarette smoking increases isoprostane formation. Life Sci 2006; 78: 894-7.

71. Montuschi P, Corradi M, Ciabattoni G, Nightingale J, Kharitonov SA, Barnes PJ. Increased 8-isoprostane, a marker of oxidative stress, in exhaled condensate of asthma patients. Am J Respir Crit Care Med 1999; 160: 216-20.

72. Wood LG, Fitzgerald DA, Gibson PG, Cooper DM, Garg ML. Lipid peroxidation as determined by plasma isoprostanes is related to disease severity in mild asthma. Lipids 2000; 35: 967-74.

73. Baraldi E, Ghiro L, Piovan V, Carraro S, Ciabattoni G, Barnes PJ. Increased exhaled 8-isoprostane in childhood asthma. Chest 2003; 124: 25-31.

74. Carpenter CT, Price PV, Christman BW. Exhaled breath condensate isoprostanes are elevated in patients with acute lung injury or ARDS. Chest 1998; 114: 1653-9.
75. Collins CE, Quaggiotto P, Wood L, O’Loughlin EV, Henry RL, Garg ML. Elevated plasma levels of $F_{2 \alpha}$ isoprostane in cystic fibrosis. Lipids 1999; 34: 551-6.

76. Ciabattoni G, Davi G, Collura M, Iapichino L, Pardo $\mathrm{F}$, Ganchi A. In vivo lipid peroxidation and platelet activation in cystic fibrosis. Am J Respir Crit Care Med 2000; 162: 1195-201

77. Montuschi P, Kharitonov SA, Ciabattoni G, Corradi M, van Rensen L, Geddes DM. Exhaled 8-isoprostane as a new non-invasive biomarker of oxidative stress in cystic fibrosis. Thorax 2000; 55: 205-9.

78. Cracowski JL, Cracowski C, Bessard G, Pepin JL, Bessard J, Schwebel C. Increased lipid peroxidation in patients with pulmonary hypertension. Am J Respir Crit Care Med 2001; 164: 1038-42.

79. Pratico D, Basili S, Vieri M, Cordova C, Violi F, Fitzgerald GA. Chronic obstructive pulmonary disease is associated with an increase in urinary levels of isoprostane $\mathrm{F}_{2 \alpha}$-III, an index of oxidant stress. Am J Respir Crit Care Med 1998; 158: 1709-14.

80. Montuschi P, Collins JV, Ciabattoni G, Lazzeri N, Corradi M, Kharitnov SA. Exhaled 8-isoprostane as an in vivo biomarker of lung oxidative stress in patients with COPD and healthy smokers. Am J Respir Crit Care Med 2000; 162: 1175-7.

81. Montuschi P, Ciabattoni G, Paredi P, Pantelidis P, du Bois RM, Kharitnov SA. 8-Isoprostane as a biomarker of oxidative stress in interstitial lung diseases. Am J Respir Crit Care Med 1998; 158: 1524-7.

82. Morris JM, Gopaul NK, Endresen MJ, Knight M, Linton EA, Dhir S. Circulating markers of oxidative stress are raised in normal pregnancy and pre-eclampsia. Br J Obstet Gynaecol 1998; 105: 1195-9.

83. Ishihara O, Hayashi M, Osawa H, Kobayashi K, Takeda S, Vessby B. Isoprostanes, prostaglandins and tocopherols in pre-eclampsia, normal pregnancy and non-pregnancy. Free Radic Res 2004; 38: 913-8.

84. Regan CL, Levine RJ, Baird DD, Ewell MG, Martz KL, Sibai BM. No evidence for lipid peroxidation in severe preeclampsia. Am J Obstet Gynecol 2001; 185: $572-8$

85. Walsh SW, Vaughan JE, Wang Y, Roberts LJ II. Placental isoprostane is significantly increased in preeclampsia. Faseb J 2000; 14: 1289-96.

86. Barden A, Ritchie J, Walters B, Croft KD, Walters BN, Michael CA. Study of plasma factors associated with neutrophil activation and lipid peroxidation in preeclampsia. Hypertension 2001; 38: 803-8.

87. Barden A, Beilin LJ, Ritchie J, Croft KD, Walters BN, Michael CA. Plasma and urinary 8-iso-prostane as an indicator of lipid peroxidation in pre-eclampsia and normal pregnancy. Clin Sci (Lond) 1996; 91: 711-8.

88. Perrone S, Longini $\mathrm{M}$, Bellieni $\mathrm{CV}$, et al. Early oxidative stress in amniotic fluid of pregnancies with Down syndrome. Clin Biochem 2007; 40: 177-80.

89. Montine TJ, Beal MF, Cudkowicz ME, O'Donnel H, Margolin RA, McFarland L. Increased $\mathrm{CSF} \mathrm{F}_{2^{-}}$ isoprostane concentration in probable AD. Neurology 1999; 52: 562-5. 
90. Montine TJ, Markesbery WR, Zackert W, Sanchez SC, Roberts LJ II, Morrow JD. The magnitude of brain lipid peroxidation correlates with the extent of degeneration but not with density of neuritic plaques or neurofibrillary tangles or with APOE genotype in Alzheimer's disease patients. Am J Pathol 1999; 155: 863-8.

91. Pratico D, Clark CM, Lee VM, Trojanowski JQ, Rokach J, FitzGerald GA. Increased 8,12-iso-iPF $2 \alpha^{-}$ VI in Alzheimer's disease: correlation of a noninvasive index of lipid peroxidation with disease severity. Ann Neurol 2000; 48: 809-12.

92. Feillet-Coudray C, Tourtauchaux R, Niculescu M, Rock E, Tauveron I, Alexandre-Gouabau MC, et al. Plasma levels of 8-epiPGF $2 \alpha$, an in vivo marker of oxidative stress, are not affected by aging or Alzheimer's disease. Free Radic Biol Med 1999; 27: 463-9.

93. Montine TJ, Quinn JF, Milatovic D, Silbert LC, Daug T, Sanchez S. Peripheral $F_{2}$-isoprostanes and $\mathrm{F}_{4}$-neuroprostanes are not increased in Alzheimer's disease. Ann Neurol 2002; 52: 175-9.

94. Montine TJ, Shinobu L, Montine KS, Roberts II LJ, Knowall NW, Beal MF. No difference in plasma or urinary $\mathrm{F}_{2}$-isoprostanes among patients with Huntington's disease or Alzheimer's disease and controls. Ann Neurol 2000; 48: 950.

95. Montine TJ, Beal MF, Robertson D, O’Donnell H, Cudkowicz ME, Biaggioni I, et al. Cerebrospinal fluid $\mathrm{F}_{2}$-isoprostanes are elevated in Huntington's disease. Neurology 1999; 52: 1104-5.

96. Fessel JP, Hulette C, Powell S, Roberts LJ II, Zhang J. Isofurans, but not $\mathrm{F}_{2}$-isoprostanes, are increased in the substantia nigra of patients with Parkinson's disease and with dementia with Lewy body disease. J Neurochem 2003; 85: 645-50.

97. Helmersson J, Mattsson P, Basu S. Prostaglandin $F_{2 \alpha}$ metabolite and $\mathrm{F}_{2}$-isoprostane excretion rates in migraine. Clin Sci (Lond) 2002; 102: 39-43.

98. Monga M, Dunn K, Rajasekaran M. Characterization of ultrastructural and metabolic abnormalities in semen from men with spinal cord injury. J Spinal Cord Med 2001; 24: 41-6.

99. Mattsson N, Haghighi S, Andersen O, Yao Y, Rosengren $\mathrm{L}$, Brennow $\mathrm{K}$. Elevated cerebrospinal fluid $\mathrm{F}_{2^{-}}$ isoprostane levels indicating oxidative stress in healthy siblings of multiple sclerosis patients. Neurosci Lett 2007; 414: 233-6.

100. Camphausen K, Ménard C, Sproull M, Goley E, Basu $\mathrm{S}$, Coleman $\mathrm{C}$. Isoprostane levels in the urine of patients with prostate cancer receiving radiotherapy are not elevated. J Radiation Oncology, Biology, Physics 2003; 58: 1536-9.

101. Handelman GJ, Walter MF, Adhikarla R, Gross J, Dallal GE, Levin NW. Elevated plasma $\mathrm{F}_{2}$-isoprostanes in patients on long-term hemodialysis. Kidney Int 2001; 59: 1960-6.

102. Ikizler TA, Morrow JD, Roberts LJ, Evanson JA, Becker B, Hakim RM. Plasma $\mathrm{F}_{2}$-isoprostane levels are elevated in chronic hemodialysis patients. Clin Nephrol 2002; 58: 190-7.
103. Cracowski JL, Souvignet C, Quirin N, Grosbis V, Bayle F, Stanke-Labesque F. Urinary $\mathrm{F}_{2}$-isoprostanes formation in kidney transplantation. Clin Transplant 2001; 15: 58-62.

104. Basu S, Meisert I, Eggensperger E, Krieger E, Krenn CG. Time course attenuation of ischemia-reperfusion injury by propofol in human renal transplantation. Redox Report in press.

105. Lauzurica R, Pastor MC, Bayes B, Hernandez JM, Bonet J, Llopis MA. $\mathrm{F}_{2}$-isoprostanes in kidney transplant patients: relationship with inflammatory markers. Transplant Proc 2005; 37: 3842-3.

106. Minuz P, Patrignani P, Gaino S, Degan M, Menapace L, Tommsoli R. Increased oxidative stress and platelet activation in patients with hypertension and renovascular disease. Circulation 2002; 106: 2800-5.

107. Basu S, Whiteman M, Mattey DL, Halliwell B. Raised levels of $\mathrm{F}_{2}$-isoprostanes and prostaglandin $\mathrm{F}_{2 \alpha}$ in different rheumatic diseases. Ann Rheum Dis 2001; 60: $627-31$

108. Cracowski JL, Marpeau C, Carpentier PH, Imbert B, Cachot S, Stanke-Labesque F. Enhanced in vivo lipid peroxidation in scleroderma spectrum disorders. Arthritis Rheum 2001; 44: 1143-8.

109. Stein CM, Tanner SB, Awad JA, Roberts LJ II, Morrow JD. Evidence of free radical-mediated injury (isoprostane overproduction) in scleroderma. Arthritis Rheum 1996; 39: 1146-50.

110. Wolfram RM, Budinsky AC, Eder A, Presenhuber C, Nell A, Sperr W. Salivary isoprostanes indicate increased oxidation injury in periodontitis with additional tobacco abuse. Biofactors 2006; 28: 21-31.

111. Sinzinger H, Kaliman J, Oguogho A. Eicosanoid production and lymphatic responsiveness in human cigarette smokers compared with non-smokers. Lymphology 2000; 33: 24-31.

112. Montine TJ, Sidell KR, Crews BC, Markesbery WR, Marnett LJ, Roberts LJ, et al. Elevated CSF prostaglandin $E_{2}$ levels in patients with probable AD. Neurology 1999; 53: 1495-8.

113. Pratico D, My LV, Trojanowski JQ, Rokach J, Fitzgerald GA. Increased $\mathrm{F}_{2}$-isoprostanes in Alzheimer's disease: evidence for enhanced lipid peroxidation in vivo. Faseb J 1998;12:1777-83.

114. Feillet-Coudray C, Tourtauchaux R, Niculescu M, Rock E, Tauveron I, Alexandre-Gouabau MC, et al. Plasma levels of 8-epiPGF $2 \alpha$, an in vivo marker of oxidative stress, are not affected by aging or Alzheimer's disease. Free Radic Biol Med 1999; 27: 463-9.

115. Basu S, Michaelsson K, Olofsson H, Johansson S, Melhus H. Association between oxidative stress and bone mineral density. Biochem Biophys Res Commun 2001; 288: 275-9.

116. Sinaiko AR, Steinberger J, Moran A, Prineas RJ, Vessby B, Basu S. Relation of body mass index and insulin resistance to cardiovascular risk factors, inflammatory factors, and oxidative stress during adolescence. Circulation 2005; 111: 1985-91.

117. Pratico D, Tangirala RK, Rader DJ, Rokach J, FitzGerald GA. Vitamin E suppresses isoprostane 
generation in vivo and reduces atherosclerosis in ApoE-deficient mice Nat Med 1998; 4: 1189-92.

118. Meagher EA, Barry OP, Lawson JA, Rokach J, FitzGerald GA. Effects of vitamin E on lipid peroxidation in healthy persons. JAMA 2001; 285: $1178-$ 82.

119. Smedman A, Vessby B, Basu S. Isomer-specific effects of conjugated linoleic acid on lipid peroxidation in humans: regulation by alpha-tocopherol and cyclooxygenase-2 inhibitor. Clin Sci (Lond) 2004; 106: 6773.

120. Patrignani P, Panara MR, Tacconelli S, Seta F, Bucciarelli T, Ciabattoni G. Effects of vitamin E supplementation on $\mathrm{F}_{2}$-isoprostane and thromboxane biosynthesis in healthy cigarette smokers. Circulation 2000; 102: 539-45.

121. Weinberg RB, VanderWerken BS, Anderson RA, Stegner JE, Thomas MJ. Pro-oxidant effect of vitamin $\mathrm{E}$ in cigarette smokers consuming a high polyunsaturated fat diet. Arterioscler Thromb Vasc Biol 2001; 21: 1029-33.

122. Davi G, Di Minno G, Coppola A, Andria G, Cerbone AM, Madonna P. Oxidative stress and platelet activation in homozygous homocystinuria. Circulation 2001; 104: 1124-8.

123. Meagher EA, Barry OP, Burke A, Luccy MR, Lawson JA, Rokach J. Alcohol-induced generation of lipid peroxidation products in humans. J Clin Invest 1999; 104: 805-13.

124. Basu S, Lee R, Dunster C, Kelly FJ. Lipid peroxidation biomarker changes in humans in response to increa- sing doses of $\alpha$-tocopherol. Proc NY Acad Sci 2004;P12.

125. Steinberg D. Low density lipoprotein oxidation and its pathobiological significance. J Biol Chem 1997; 272: 20963-6.

126. Loscalzo J. Oxidative stress in endothelial cell dysfunction and thrombosis. Pathophysiol Haemost Thromb 2002; 32: 359-60.

127. Steinberg D, Witztum JL. Is the oxidative modification hypothesis relevant to human atherosclerosis? Do the antioxidant trials conducted to date refute the hypothesis? Circulation 2002; 105: 2107-11.

128. Steinberg D. Atherogenesis in perspective: hypercholesterolemia and inflammation as partners in crime. Nat Med 2002; 8: 1211-7.

129. Vivekananthan DP, Penn MS, Sapp SK, Hsu A, Topol EJ. Use of antioxidant vitamins for the prevention of cardiovascular disease: meta-analysis of randomised trials. Lancet 2003; 361: 2017-23.

\section{Samar Basu}

Clinical Nutrition and Metabolism

Department of Public Health and Caring Sciences

Uppsala Science Park

Faculty of Medicine

Uppsala University

SE-75I 85 Uppsala

Sweden

E-mail: samar.basu@pubcare.uu.se 